\title{
Place Attachment as Indicator for Place Significance and Value
}

\author{
Norsidah Ujang ${ }^{1 *}$, Khalilah Zakariya² \\ 1 Dept. of Landscape Architecture, Faculty of Design and Architecture, Universiti Putra Malaysia, Serdang 43400, \\ Selangor Malaysia \\ 2 Dept. of Landscape Architecture, Kulliyyah of Architecture and Environmental Design, International Islamic \\ University Malaysia, Kuala Lumpur 50728, Malaysia \\ norsidah@upm.edu.my
}

\begin{abstract}
Place attachment is a form of connection between a person and the environmental setting. In the production of urban places, planners and designers mainly focus on the quality of the physical components. However, the aspects of meanings and attachment are not adequately considered in the planning and decision-making process. This study utilizes semi-structured interview method to examine place attachment dimensions in understanding the values of a place in the life of the users. Sample cases include examining attachment to streets in the city centre of Kuala Lumpur, Malaysia. It was evident that users' roles and ethnic backgrounds influenced their responses. Attachment to the places was economically, socially and culturally oriented and prevalent in their daily experience of the places, and the place memories recalled.
\end{abstract}

Keywords: Place attachment; meaning; value; users

eISSN 2398-4295 @ 2018. The Authors. Published for AMER ABRA cE-Bs by e-International Publishing House, Ltd., UK. This is an open-access article under the CC BY-NC-ND license (http://creativecommons.org/licenses/bync-nd/4.0/). Peer-review under responsibility of AMER (Association of Malaysian Environment-Behaviour Researchers), ABRA (Association of Behavioural Researchers on Asians) and cE-Bs (Centre for EnvironmentBehaviour Studies), Faculty of Architecture, Planning \& Surveying, Universiti Teknologi MARA, Malaysia.

DOI: http://dx.doi.org/10.21834/ajbes.v3i10.84 


\subsection{Introduction}

The objective of this paper is to understand users' attachment to places within the city of Kuala Lumpur. It discusses the way in which people value a place based on qualitative inquiries. Using place-based approach, it focuses on the emotional sense of place embedded in the feeling, emotion and behaviour. Steadman (2003) noted that the physical features do not produce a sense of place directly, but influence the symbolic meanings of the landscape, which relates to the strength of place attachment. It is important to integrate the psychology of place in assessing place distinctiveness and values.

This paper advocates place-based approach and concepts in examining an attachment to urban places. Place is a space imbued with meanings (Relph, 1976). Relph explained that space and place are interconnected, where the physical aspects of space are ascribed meaning according to the values that people give to that place (Zakariya, Mohyuddin and Yaman, 2007). The physical and cultural characteristics combined with the individual's affective perceptions and functional needs shape place attachment (Bott, 2005). Experience of place is not just physical but also perceptual and psychological and users (the public), and their experience and perception are the key source of evidence in understanding place attachment and place values. Place attachment is a positive element that can contribute to sustaining place identity, and the sense of place, thus promote emotional wellbeing, fulfilment and happiness to the urban users.

\subsection{Literature Review}

\section{The value of place attachment}

The globalisation of Malaysian cities is evident in the homogeneity of buildings' scales and appearances and the loss of traditional values (Shamsudin and Ujang, 2008). These transformations have influenced the way users experienced, perceived and felt about local places and their sense of psychological wellbeing. Here, the weakening of place identity could result in the loss of meaning and disrupts emotional attachment to place (Arefi, 1999). In the case of Kuala Lumpur city, the pressure from development and demands of urban tourism over the years has resulted in the physical transformations of public spaces, including historic open space (Zakariya and Harun, 2013). As a result, new developments particularly within the traditional setting transform constructed places and established place meanings embedded in the existing social and cultural setting. Relph (1976) described placelessness as an environment without significant places and the underlying attitude which does not acknowledge the significance in places.

Place attachment relates to the affective aspects of environmental meaning (Altman and Low, 1992). It is embedded in the affective bond or link between people or individuals and particular places (Hidalgo and Hernandez, 2001). It was evident in the interplay of affects and emotions, knowledge and beliefs, and behaviours and actions (Prohansky et al., 1983). Place attachment was evident in the functional bonding between people and places described as place dependence (Stokol and Shumaker, 1981) and the desire to maintain closeness to the object of attachment (Hidalgo and Hernandez, 2001). It also describes the 
special feeling towards a particular place. This can be associated with elements of attraction, frequency of visits and level of familiarity.

Understanding on place attachment is important in sustaining the attraction and meaning of places. Human experience and behaviour are developed through a network of memories and identities attached to the environment (Cheshmehzangi and Heath, 2012).

\section{Influence of cultural characteristics}

Racial, ethnic or class identity influences sense of attachment to a particular place (Rose, 1995). The idea suggests that meanings can be categorized based on the variation in the characteristics of the people. Therefore, there is a need to identify place attachment based on consensus from stratified user groups according to their roles and socio-cultural characteristics. In this context, 'users' are those who rely on public spaces or buildings for passive and active engagement (Hassanuddin, 2003 from Francis, 1989). The length of association and the frequency of engagement influence attachment. Culture relates to beliefs and perception, values and norms, customs and mode of appropriate behaviour constitute a cluster of characteristics (Altman and Low, 1992). It is a way of life, symbols, meaning and cognition and survival strategies accepted as norms Riley (1992) discovered that the difference in landscape experience poses different form, types and degree of attachment for different cultural groups. In the case of a pluralistic society in Malaysian cities, the cultural principles play an important role in defining group identity hence influence the character and identity of the place they inhabited (Ujang, 2010).

\subsection{Methodology}

The researcher had conducted face to face interview with 24 samples representing areas covering Jalan Masjid India (JMI), JalanTuanku Abdul Rahman (JTAR), JalanPetaling (JP) and Jalan Bukit Bintang (JBB). Each street reflects particular ethnic group(s) observable through its thematic street image and the demographic profiles of its users (types of businesses, shop owners, street vendors and visitors). Criteria of samples considered include the users' length of engagement with the streets, representative of ethnic population (Malay, Chinese, Indian and Indian Muslim) as the dominant groups occupying and visiting the streets, frequency of visit (minimum once a month) and familiarity (very familiar with the area). This paper focuses on the affective values of the places expressed in the feelings about the place, memory, sense of pride and belonging.

\subsection{Results and Discussions}

\section{Place attachment}

The emotional form of attachment can provide an indication of the actual value of the streets based on the affective reactions towards qualities associated with the places. The respondents expressed the sense of happiness, positive impression, sentiment and care. 
Ujang, N., \& Zakariya, K. / Asian Journal of Behavioural Studies (AjBeS), 3(10) Mar / Apr 2018 (p.95-103)

Table 1: Emotional attachment indicators

\begin{tabular}{|c|c|c|c|}
\hline \multirow{2}{*}{ Indlcators } & \multicolumn{3}{|c|}{ Place } \\
\hline & JMI/JTAR & $\mathrm{JP}$ & JEB \\
\hline \multirow[t]{4}{*}{ Happiness } & $\begin{array}{l}\text { Feel happy workingbusiness in } \\
\text { the area }\end{array}$ & $\begin{array}{l}\text { Lively place and happy being } \\
\text { there }\end{array}$ & $\begin{array}{l}\text { Uvely place and happy } \\
\text { belng there }\end{array}$ \\
\hline & $\begin{array}{l}\text { Happy with changes and } \\
\text { improvement }\end{array}$ & $\begin{array}{l}\text { Happy and satisfled with the } \\
\text { physlcal changes }\end{array}$ & $\begin{array}{l}\text { More entertaining spots } \\
\text { More places to shop }\end{array}$ \\
\hline & $\begin{array}{l}\text { Happy with the cholces of goods } \\
\text { and price range }\end{array}$ & $\begin{array}{l}\text { Feel happy workinglousiness in } \\
\text { the area }\end{array}$ & More tourists and visitors \\
\hline & & $\begin{array}{l}\text { Enjoy the busting atmosphere } \\
\text { Happy looking at people pedding }\end{array}$ & \\
\hline \multirow[t]{4}{*}{$\begin{array}{l}\text { Positive } \\
\text { Impression }\end{array}$} & $\begin{array}{l}\text { Positive about the ambiance of } \\
\text { the place }\end{array}$ & $\begin{array}{l}\text { Positve with the character of the } \\
\text { place }\end{array}$ & $\begin{array}{l}\text { Uke the Ilvely } \\
\text { environment, full of people }\end{array}$ \\
\hline & $\begin{array}{l}\text { Posittive about creating beter } \\
\text { physical image }\end{array}$ & $\begin{array}{l}\text { Like the street's particular } \\
\text { atmosphere that cannot be found } \\
\text { In the shopping complexes }\end{array}$ & and vlbrant \\
\hline & & $\begin{array}{l}\text { Weicome promotion of the place } \\
\text { for increased popularity }\end{array}$ & the street \\
\hline & & $\begin{array}{l}\text { Positve about the distinct } \\
\text { atmosphere }\end{array}$ & \\
\hline \multirow[t]{9}{*}{$\begin{array}{l}\text { Sentment- } \\
\text { Care }\end{array}$} & $\begin{array}{l}\text { Reslstance to relocating the } \\
\text { vendors }\end{array}$ & $\begin{array}{l}\text { Reslstance to relocating the } \\
\text { vendors }\end{array}$ & \multirow{2}{*}{$\begin{array}{l}\text { Criticlsm on the lack of } \\
\text { Malay businesses and lack } \\
\text { of opportunities for Malay } \\
\text { traders }\end{array}$} \\
\hline & \multirow{2}{*}{$\begin{array}{l}\text { Feel upset if they are relocated } \\
\text { to other less famillar location } \\
\text { and isolated from the main } \\
\text { pedestrian movement }\end{array}$} & $\begin{array}{l}\text { Defensive about changes of } \\
\text { physical settings }\end{array}$ & \\
\hline & & $\begin{array}{l}\text { Sensitive about the physica: } \\
\text { changes and the diflculty caused }\end{array}$ & $\begin{array}{l}\text { Felt that the place is more } \\
\text { appropriate to youngsters }\end{array}$ \\
\hline & \multirow{2}{*}{$\begin{array}{l}\text { Feel threatened with the } \\
\text { decrease in visitors-reduced in } \\
\text { monetary gain }\end{array}$} & by It & and tourists \\
\hline & & Care about the cleanliness & \multirow[t]{5}{*}{$\begin{array}{l}\text { Cleaner and more } \\
\text { organised spaces }\end{array}$} \\
\hline & Sentment over changes & $\begin{array}{l}\text { Strong social connection and } \\
\text { bonding due to engagement to }\end{array}$ & \\
\hline & $\begin{array}{l}\text { Defensive about changes of } \\
\text { physical settings }\end{array}$ & $\begin{array}{l}\text { similar types of activities and } \\
\text { simllar cuitural group }\end{array}$ & \\
\hline & $\begin{array}{l}\text { Concern on degree of crime and } \\
\text { social lis and economic } \\
\text { sustainability of own group }\end{array}$ & \multirow{2}{*}{$\begin{array}{l}\text { A place of social interacton } \\
\text { based on family oriented } \\
\text { economic activitles }\end{array}$} & \\
\hline & $\begin{array}{l}\text { Concem about drug addiction } \\
\text { activity and vandalsm of facility } \\
\text { Contested space }\end{array}$ & & \\
\hline
\end{tabular}

(Source: Author)

Stronger feelings were felt in the form of a stronger sense of dissatisfaction towards arising issues affecting the places. Respondents from JMI and JP expressed sentiments towards the contestation of street vending area by illegal intruders, conflicting of interests and dissatisfaction on the physical changes and improvement. However, after the upgrading of both streets was completed, vendors and visitors acknowledged that the conditions of the street markets were better. It can be inferred that the motive of the negative reaction was mainly to protect the traders' spatial 'territory' and from the domination of illegal traders in the area. In the case of JMI, the impact of changes has caused conflicting reactions from the streets' users particularly the street vendors, the shop owners and the attached community members. The street vendors (with more than 20 years engagement with the street) as a 
living component of the place have contributed to the unique identity of the traditional shopping street. Table 1 summarizes the affective reactions towards the places.

The respondents shared not only their knowledge about the places but also sentiments, pride, loyalty and love of the places. Their commitment was strongly associated with the roles of the place in developing the sense of 'ownership' and 'territoriality' reflecting the self and group identity. The functional and social attachment also developed due to the frequency and the length of engagement. Shoppers expressed the feeling of enjoyment with the distinct atmosphere of the streets strongly manifested in the activity and well supported by the spatial and physical setting of the place. In this regard, diversity has affected the resident's attachments as it affords different types of social interaction and various types of good selection (Harun et. al, 2013). The mixture of users (local and foreign tourists) creates diversity of activities (Ja'afar et. al., 2012). This is parallel to Relph's theory (1976) that the sense of place is embedded in the feelings and perceptions that people have through experience of a place as well as referring to the qualities of a place that make it distinctive from other places. The cultural spaces imbued people's way of life and devoted cultural phenomenon are essential to build a place identity (Lai, 2013).

\section{The influence of culture and ethnicity}

Attachment to the places is reflected emotionally with the influence of the physical and the cultural characteristics of the people and the setting. Cultural identity distinguishes one ethnic group's setting from another. It was apparent that the cultural expression strongly manifested during ethnic festivals, the items sold and the general atmosphere of the shopping streets. Hari Raya of Eid, a celebration for the Muslims across culture after a month long of fasting transforms the image of the shopping streets except JP where the majority of traders are Chinese. Here, the Malay and the Indian Muslims celebrate the festival every year as cultural symbols and religious practices. The products distinct to the streets (JMI-TAR, JP) indicate the dominance of the ethnic group rooted from the early ethnic settlement.

The cultural influence strongly manifested in the respondents' sense of belonging and meaning associated with the places. The Indian Muslim respondents in JMI associated the attachment to others from similar ethnic background. There is an established sense of community expressed by the users regulated by daily religious practices in the Indian Mosque. The meanings, therefore, varied according to the cultural background of the users. The streets become the channel to the continuity of self and community identity. (JMI-TAR and JP) Findings indicate that the Indian Muslims and the Indians indicate a stronger attachment indication to the places and the people within it. It is also true to JP ad JTAR as traditional streets. JBB manifests the mixture of cultural content that is influenced by the western and modern lifestyles. The 'globalised' culture has almost diminished the ethnic root established in the early settlement of the area. An attachment varied between ethnicity in JMI-TAR. The Indian Muslim and Indian respondents indicated stronger emotional and sociocultural attachment compared to the Malay respondents. To describe the difference, the Indian Muslims are the key users involved in the trading activities and occupied the premises along JMI-TAR. Their sense of belonging was evident in the social interaction among the Indian Muslims and religious commitment. Interviews with respondents from JMI-TAR 
indicate that the length of engagement, family-inherited businesses and socio-cultural bonding enhance the attachment. Chinese respondents (shop owners) from JP experienced similar regarding improvement of the place. In the case of JBB, the findings suggest that the Malay and Chinese respondents share common feelings about the streets and less influenced by conflicting interests and negative emotional responses towards local issues. This may be contributed to the generic identity of the modern appearance of JBB.

In summary, the ethnic identity and related economic and social issues influence users' attachment to the shopping streets. It contributes to the sense of place. This concurs with the theories that a strong sense of attachment to a particular place influenced by racial and ethnic identity Rose (1995). The culture of the people influences the environmental reaction towards a setting (Rapoport, 1977).

\section{Place memory}

Demographic factors such as age, gender, and ethnic play an important role in prescribing one's attachment and ability to remember of certain things or events (Othman et. al., 2013). Place memory indicated the significance of the place to one's life experience. The finding shows that particular experiences recalled by the respondents that evoked their emotions. Those included the main physical and social changes together with a particular moment of interaction with certain types of customers (shoppers). It also includes childhood memory of being in the streets with family, exciting festive and entertaining environment, cultural events, relocation due to the physical improvement, confronting intruders and the experience of stolen belongings. The following statements reflect the memory associated with JMI-TAR:

"Dulu JTAR yang paling dulu berkembang dan dikenali, sekarang sampai ke JMI seba btambah ramai orang India dan Melayu".

"In the past, JTAR was the first to develop and known, it was then extended to JMI because of the coming of more Indians and Malays". (Malay Respondent 10: Resident, 15 years of engagement) JMI. Continuity of place attachment embedded in the memory, however, continues to be threatened by the transformation of places. JTAR popularly known as BatuRoad, holds fond memories for city folks who used to shop at the popular street during the early 1960s and 1970s. Today, it is struggling to keep up with the image of modern shopping malls (Star Metro, 25 Oct 2005).

Memories mentioned by respondents in JP associated with shared activities and the physical changes. The memories include shopping with the parent during childhood, the changing of the place as compared to the present, going to the cinema close to JP during younger years with friends, buying traditional Chinese candies, taking daily 'tea and coffee' with other neighbouring traders and memory of running a stall with the late parents. The following responses indicate the moments:

"I can recall my everyday life of waking up early and arranging my wares; and my daily 'tea and coffee' with neighbouring stalls and shops". (Chinese Respondent 3: Shopkeeper, 26 years of engagement).

In summary, familiarity and frequent engagement developed sense of belonging expressed by strong emotional feelings. It was translated in the form of pride due to the distinct 
characteristics of the places and sense of ownership to trading spaces as well as an attachment to the economic and religious practices. The symbolic importance of a place as a repository for emotions and relationships give meaning and purpose to life. According to Kamalipouret. al (2012), community attachment is significant, and neighbourhoods play the most prominent role in people's attachment to the place. Places have different levels of sense of place that contribute to social activities based on the relationships of place meaning (Nik Muhamad et. al, 2013). Table 2 summarizes meanings associated with the places as expressed by the respondents.

Table 2. Meanings of place

\begin{tabular}{|c|c|c|c|}
\hline \multirow{2}{*}{ Ind cators } & \multicolumn{3}{|c|}{ Place } \\
\hline & JMITAR & $J P$ & JBB \\
\hline Loyasty & $\begin{array}{l}\text { Not willing to move due to its } \\
\text { strategic location and as a } \\
\text { pedestrian route } \\
\text { Wish to stay because of } \\
\text { famillarity with people and long } \\
\text { tem engagement } \\
\text { Long for amblance of the place }\end{array}$ & $\begin{array}{l}\text { Unwilling to move to other place } \\
\text { due to being accustomed with the } \\
\text { place } \\
\text { Unwiling to leave the place if } \\
\text { glven a cholce because the } \\
\text { business has been established in } \\
\text { the street } \\
\text { Unwiling to move to other places } \\
\text { due to having many friends } \\
\text { Continuing business from } \\
\text { generations } \\
\text { Attachment due to frequent visits }\end{array}$ & $\begin{array}{l}\text { Wil not move to other } \\
\text { places because of feeling } \\
\text { comfortable and satsfying } \\
\text { living in the area } \\
\text { Not wiling to move to other } \\
\text { places due to good } \\
\text { business and famllarity } \\
\text { With people and the area } \\
\text { Prefer to settle in the area } \\
\text { after retrement due to } \\
\text { famliarty }\end{array}$ \\
\hline Prde & $\begin{array}{l}\text { Sense of pride due to popularity } \\
\text { and distinctiveness } \\
\text { Strong attachment to the } \\
\text { mosque as symbols of } \\
\text { community } \\
\text { Strong sense of ownership and } \\
\text { bonding due to longer perlod of } \\
\text { engagement }\end{array}$ & $\begin{array}{l}\text { Sense of pride due to popularity } \\
\text { and distinctiveness } \\
\text { suggested people to visit the } \\
\text { place more } \\
\text { Proud of the special quality of the } \\
\text { place Proud of the place due to } \\
\text { Its uniqueness } \\
\text { Proud of the speciaity of } \\
\text { traditional food and eateries } \\
\text { Proud to run a business in the } \\
\text { street. It's a family legacy. } \\
\text { Proud with relationship with other } \\
\text { traders (friends) } \\
\text { Be able to business in the street } \\
\text { Is a privilege and respected by } \\
\text { others }\end{array}$ & $\begin{array}{l}\text { Proud of the old Hotel } \\
\text { Malaya and notice the } \\
\text { physical changes in the } \\
\text { street } \\
\text { Proud of the popularity of } \\
\text { the streets to foreign } \\
\text { tourists } \\
\text { I am proud of this place } \\
\text { because it's the place I } \\
\text { worked from my younger } \\
\text { days }\end{array}$ \\
\hline Love & $\begin{array}{l}\text { Love the piace and wish to stay } \\
\text { and work there as long as } \\
\text { possible }\end{array}$ & $\begin{array}{l}\text { Love the place and know very } \\
\text { wel about the place } \\
\text { Love the place and like to feel the } \\
\text { atmosphere }\end{array}$ & $\begin{array}{l}\text { Love the place for a walk } \\
\text { and window shopping and } \\
\text { ooserving people and } \\
\text { actlvitles } \\
\text { Love to walk and shop } \\
\text { because there are a lot of } \\
\text { shopping complexes }\end{array}$ \\
\hline
\end{tabular}

(Source: Author) 


\subsection{Conclusion}

Place attachment provides an indicator of the significance and meaning of a place to the immediate users. The significance in identifying users according to their demographic characteristics and roles is an appropriate approach in understanding the actual values of a place to a specific group of users. It is also to examine their sensitivity and concern towards the places. This understanding will assist the implementation process in the intervention projects concerning various types of users occupying the business premises that regard the places (streets) as significant in sustaining the economy and the cultural identity. This is to secure attachment of the people to their environmental setting. In this case, it can be concluded that place attachment will contribute to the preservation of local place identity and continuity of personal and cultural identity.

\section{Acknowledgement}

The authors would like to acknowledge the Ministry of Higher Learning of Malaysia for funding this research and Universiti Putra Malaysia in providing the research facilities.

\section{References}

Altman, I., \& Low, S. (1992). Place attachment. New York: Plenum Press.

Bott, S. ,Cantrill, G. J., \&Myers, E. O. Jr. (2003). Place and the promise of conservation psychology. HumanEcology Review, 10(2), 100-112.

Cheshmehzangi, A., \& Heat, T. (2012). Urban identities: Influences on socio-environmental values and spatial interrelations. Procedia-Social and Behavioral Sciences, 36, 253-264.

Harun, N. Z., Mansor, M., \& Said, I. (2013).The experience of diversity in open spaces of two historical towns in Malaysia. Procedia-Social and Behavioral Sciences, 85, 582-591.

Hasanudin, L. (2003). A Comparative analysis of perception of urban landmarks between designers, non-designers and laypublic: Kuala Lumpur Malaysia. Unpublished PHD Thesis, University of Sheffield.

Hidalgo, M. C., \& Hernandez, B. (2001). Place attachment: Conceptual and empirical questions.Journal of Environmental Psychology,21, 273-281.

Ja'afar, N. H., Sulaiman, A. B., \&Shamsuddin, S. (2012). The contribution of landscape features on traditional streets in Malaysia. Procedia-Social and Behavioral Sciences, 50, 643-656.

Lai, L. Y., Said, I., \& Kubota, A. (2013). The roles of cultural spaces in Malaysia's historic towns: The case of Kuala Dungun and Taiping. Procedia-Social and Behavioral Sciences, 85, 602-625.

Mohammad, N. M. N., Saruwono, M., Said, S. Y., \& Hariri, W. A. H. W. (2013). A sense of place within the landscape in cultural settings. Procedia-Social and Behavioral Sciences, 105, 506-512.

Othman, S., Nishimura, Y., \& Kubota, A. (2013).Memory association in place making: A review. Procedia-Social and Behavioral Sciences, 85, 554-563. 
Proshansky, H. M., Fabian A. K., \&Kamikoff, R. (1995). Place identity: Physical world socialisation of the self. (pp.87113). In L. Groat (Ed.) Giving places meaning, reading in environmental psychology.

Punter, J. (1991).Participation in the design of urban space. Landscape Design, 200, 24-27.

Relph, E. (1976). Place andplacelessness. Pion: London.

Riley, B.R. (1992). Attachment to the ordinary landscape. In I.,Altman, \&S.,Low.Place attachment. New York: Plenum Press.

Sakip, S. R. M., Johari, N., Abdullah, A., \&Salleh, M. N. M. (2013).Assessing sense of community dimension in residential areas in the Malaysian Context.Procedia-Social and Behavioral Sciences, 105, 655-663.

Shamsuddin, S., \&Ujang, N. (2008). Making places: The role of attachment in creating the sense of place for traditional streets in Malaysia. Habitat International, 32(3), 399-409.

Stedman, C.R. (2003). Is it really just a social construction?: The contribution of the physical environment to sense of place. Society and Natural Resources, 16, 671-685.

Stokols, D., \&Shumaker, S. A. (1981).People in places: A transactional view of settings.In Harvey, J. H. (Ed.).Cognition social behaviour and the environment.(pp.441-488)Hillsdale, NJ: Lawrence Erlbaum Assoc.

Ujang, N. (2010).Place attachment and continuity of urban place identity.Asian Journal of Environment-Behavior Studies, 11, 41-74.

Zakariya, K., \&Harun, N. Z. (2013). The people's dataran: Celebrating historic square as a potential temporary market space. Procedia-Social and Behavioral Sciences, 85, 592-601.

Zakariya, K., Mohyuddin, A., \& Yaman, M. (2007). Refining tourist's place experience through placemaking: Concepts and correlations. International Journal of Diversity in Organisations, Communities \& Nations, 4, 249-257. 